\title{
The Influence of the Growth of the Number of Microbreweries on the Use of Farmland and on the Cultivation of Hops in the Czech Republic: A Case Study
}

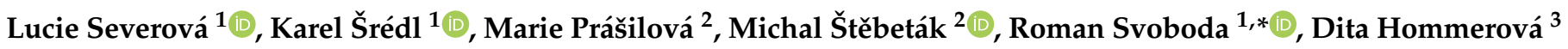 \\ and Lenka Kopecká ${ }^{1}$ \\ 1 Department of Economic Theories, Faculty of Economics and Management, Czech University of Life Sciences \\ Prague, Kamýcká 129, 16500 Prague, Czech Republic; severova@pef.czu.cz (L.S.); sredl@pef.czu.cz (K.Š.); \\ kopeckal@pef.czu.cz (L.K.) \\ 2 Department of Statistics, Faculty of Economics and Management, Czech University of Life Sciences Prague, \\ Kamýcká 129, 16500 Prague, Czech Republic; prasilova@pef.czu.cz (M.P.); stebetak@pef.czu.cz (M.Š.) \\ 3 Department of Marketing, Trade and Services, Faculty of Economics, University of West Bohemia, \\ Univerzitní 8, 30614 Pilsen, Czech Republic; hommer@kmo.zcu.cz \\ * Correspondence: svobodar@pef.czu.cz; Tel.: +420-224-382-156
}

check for

updates

Citation: Severová, L.; Šrédl, K.; Prášilová, M.; Štěbeták, M.; Svoboda, R.; Hommerová, D.; Kopecká, L. The Influence of the Growth of the

Number of Microbreweries on the Use of Farmland and on the Cultivation of Hops in the Czech Republic: A Case Study. Land 2021, 10, 784. https:// doi.org/10.3390/land10080784

Academic Editor: Carlos Parra-López

Received: 3 June 2021

Accepted: 23 July 2021

Published: 26 July 2021

Publisher's Note: MDPI stays neutra with regard to jurisdictional claims in published maps and institutional affiliations.

Copyright: (c) 2021 by the authors. Licensee MDPI, Basel, Switzerland. This article is an open access article distributed under the terms and conditions of the Creative Commons Attribution (CC BY) license (https:// creativecommons.org/licenses/by/ $4.0 /)$.

\begin{abstract}
The purpose of this study is to express the perspective of development of the hop field area in connection with the growing number of microbreweries and the popularity of special beers in Czechia. Czech beer is a concept all over the world, it comes not only from 45 large industrial breweries, including world-famous breweries from Pilsen, Prague or České Budějovice, but is also produced in more than 480 small breweries (microbreweries), many of which are traditional family businesses. With a consumption of 141 L per person in 2018, the Czechs are among the world's largest beer consumers and they have already surpassed even the Irish and Germans. The research performed confirmed the validity of the hypothesis about a slight positive effect of the growth in the number of microbreweries and the production of special beers on the extent of the hop field area in Czechia. In addition to the interpretation of new beer styles, this article also discusses the emergence of new aromatic hop varieties, the development of beer tourism and new sales opportunities for hop growers.
\end{abstract}

Keywords: agriculture; beer; beer tourism; consumer; hop; industrial breweries; microbreweries; monopolistic competition; special beer; sustainable development

\section{Introduction}

Czech beer is a concept all over the world and world brands such as Plzeňský Prazdroj, Budějovický Budvar or Pražský Staropramen belong among the signboards of the Czech brewing industry. Therefore, it is no surprise that beer is one of Czechia's leading export items and that more than 2 million hectoliters are exported each year [1].

Beer consumption of $141 \mathrm{~L}$ per person in 2018 is one of the highest in the world [2]. In addition to the number of liters drunk per person, the range of beers, such as special beers, is also expanding.

In Czechia, there is everything that beer production requires. Hop, malt and water are, in addition to yeast, the three most important ingredients for beer production. In addition, all these ingredients are found here in sufficient quantity and required quality. Hop is grown in only a few places in Czechia, due to its susceptibility to soil quality. The total area of hop fields in 2019 in Czechia was about 5003 hectares with a total final production of 7145 tons. The vast majority of hop fields were located in areas around Žatec, Tršice or Úštěc (see Figure 1). The Czech hop represents only about 7\% of the world market in terms of the volume of its production, but it is one of the best, and Žatecký poloraný červeňák is a big concept in the world of brewing [3]. 


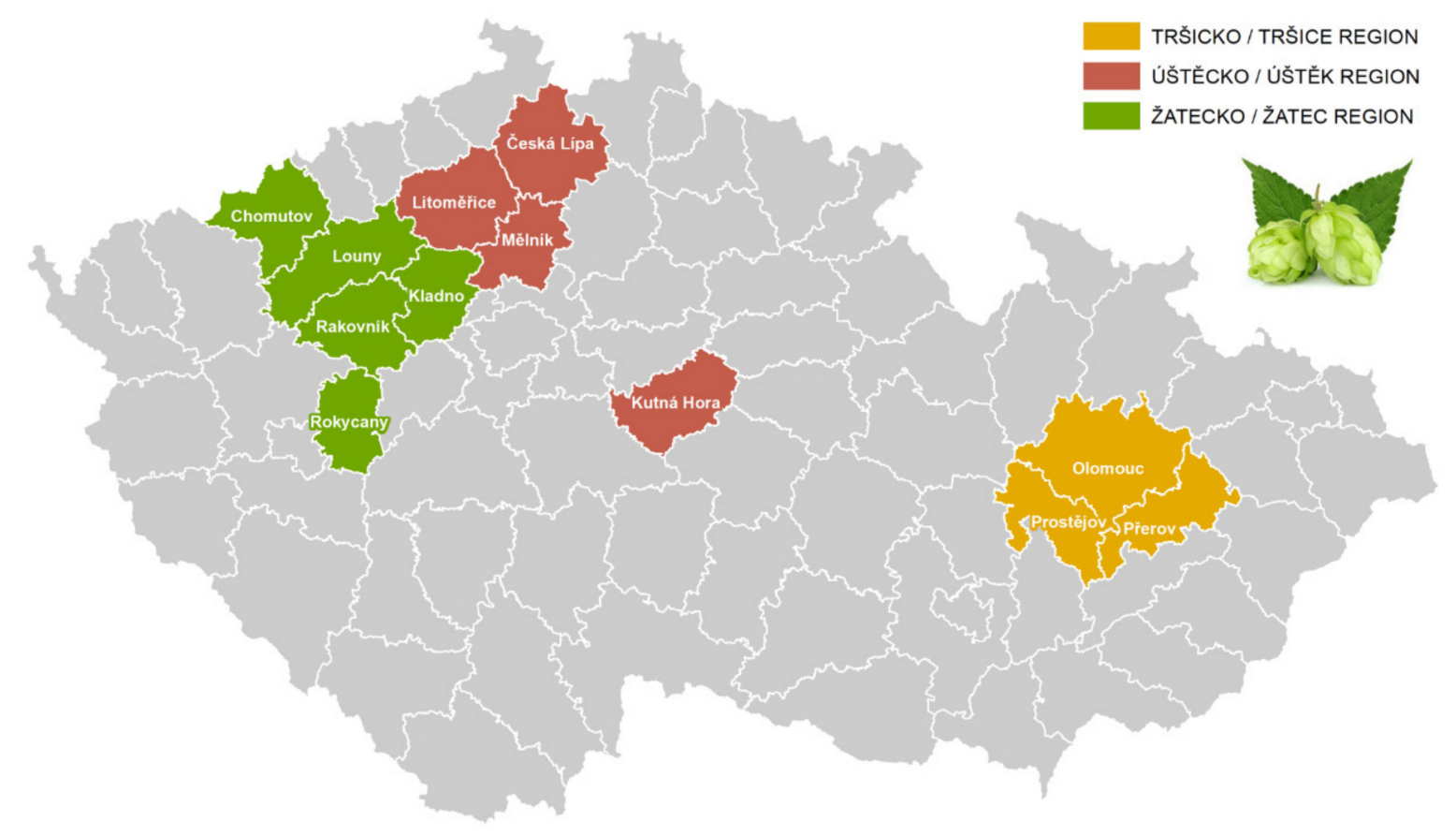

Figure 1. The map of hop-growing areas in the Czech Republic; own processing based on [4].

The Czech beer comes not only from 45 large industrial breweries, including worldfamous breweries from Pilsen, Prague or České Budějovice, but is also produced in more than 480 small breweries (microbreweries), many of which are traditional family businesses [1].

In order to unambiguously determine the subject of research, it is also necessary to define a small brewery, or a microbrewery, as an economic entity in terms of applicable legal standards. Current Czech legislation defines a small independent brewery as a brewery whose annual beer production does not exceed 200,000 hectoliters and is not legally or economically dependent on another brewery. This means that another brewery does not have more than $50 \%$ of the voting share. The term microbrewery is not defined in the Czech legal system, but in practice it is considered a brewery with a production of up to 10,000 hectoliters per year [5].

Domestic microbrewing is currently accompanied by several significant trends, some of which are completely new and others have only added to the intensity. These important trends are mainly represented by new beer styles, as well as home-brewing, beer tourism and the so-called flying breweries.

In order to ensure the increasing production of specialty beers by microbreweries in Czechia, the expansion of hop fields planted with suitable hop varieties is necessary. Thus, the necessary hop varieties will not need to be imported from abroad. However, the expansion of the area of hop fields by about 500 ha by 2030 should not have a negative impact on the production of other agricultural crops in Czechia, as many of them are largely imported from other countries where they are grown under more economically advantageous conditions. At the same time, it will enable meaningful use of farmland for profitable production of agricultural crops.

In scientific literature, there is a research gap about the connection between the development of the extent of the hop field area the growing number of microbreweries in Czechia This paper is trying to fill this gap.

The purpose of this study is to express the perspective of development of the hop field area in connection with the growing number of microbreweries and the popularity of special beers in Czechia; the planting of hop fields with new hop varieties suitable for the production of special beers by microbreweries will also contribute to this development; these beers are called craft beers in the USA. 


\section{Literature Review}

Hop-growing has a great tradition in Czechia and it remains in the interest of Czech farmers to further develop this sector of crop and plant production. The first documented hop cultivation in Bohemia was in the 8th century $\mathrm{CE}$, and hops were exported to neighboring countries as early as the beginning of the second millennium CE [6]. Hops, especially of the Saaz variety (Žatecký poloraný červeňák), are a traditional Czech export commodity.

Hop is a dicotyledonous plant of the family Cannabaceae. There are two types of hop: wild hops (ornamental plant or animal fodder) and the economically important commercial hop varieties. Hop flowers (seed cones) contain aromatic substances, resin and tannins that are important in beer-brewing [7]. As reported by Sbardella et al. [8], hop (Humulus lupulus L.) has a wide diversity of secondary metabolites with functional properties, such as bitter acids, essential oils and flavonoids, with health applications on lifestyle-related diseases, inflammation and antioxidants.

Beers from microbreweries, such as the ALE type, are very heavily hopped, often with an emphasis not only on bitterness, but also on the strong aroma of some hop varieties. The type of hop products and the hopping regime used have an impact on the perceived bitterness of the beer [9]. According to Hough et al. [10] the bitter taste of beer is an important taste attribute that consumers expect and enjoy to varying degrees during consumption. To impart bitterness, and hop aroma, brewers conventionally add hops to wort and boil for a duration of an hour to $90 \mathrm{~min}$ [11]. Schönberger and Kostelecky [12] further add that for hop aroma, brewers can 'late-hop' the beer by adding part of the total weight of hops required for the beer recipe towards the end of the boil.

The time of hop addition and the hop varieties used for beer production have been documented as factors that can influence the quality of bitterness [13]. The effect of hop aroma on the perceived bitterness of beer was also investigated, with findings showing that hop aroma significantly influences both the perceived bitterness and the character of a beer [14]. It is clear that some of bitterness attributes are in normal usage considered positive ('harmonious') whilst others (e.g., 'harsh') might be considered less desirable. In this regard, the intensity of bitterness corresponds to the magnitude of bitter taste sensation perceived, whilst temporal profile represents the time-course of bitterness intensity over a period of time [15].

One of the ways to increase yield and quality is to produce durable hop lines. Resistance breeding can be significantly improved and accelerated by using marker assisted selection [16]. In the 1990s, the methodology of hop breeding was innovated in the Czech Republic. This innovation resulted in the registration of the new variety Agnus in 2001. The Agnus variety is the first high-alpha hop in the range of Czech hop varieties [17]. According to Patzak [18], it was necessary to prepare a quality system for identification of Agnus from other Czech genotypes and to characterize the germplasm of this variety by molecular methods. "Zatecky polorany cervenak" is the dominant hop variety in the Czech Republic, making up $82.56 \%$ of the total hop production in 2016. The Sladek variety was in second place with a $4.44 \%$ share, before the Premiant variety in third place with $3.49 \%$. The remaining $9.51 \%$ falls to the other varieties grown in the Czech Republic.

However, suitable farmland is necessary for growing hops. Farmland is one of the most important productive assets of rural households in many countries, and it can be sold, leased or exchanged [19-22]. The development of agricultural business on the land is essential given the need for food production for the world's growing population. However, the area of land suitable for agricultural use is still declining in Czechia. Land distribution is the main core of economic development analysis [23]. Huettel et al. [24] deal with the price of farmland in their article and state that land is undoubtedly the most important factor of production, with a limited overall supply that is even steadily declining as it is phased out for recreational or ecological offset areas, or because it is needed for buildings or street construction. However, in the last decades, there have been large areas of agricultural land that were abandoned in Europe, producing significant social and environmental impacts [25]. Xie et al. [26] add that the abandonment of agricultural 
land has significant impacts on biodiversity and ecosystem restoration, as well as on food security and sustainable rural development.

Sustainable development is one of the main objectives of the European Union. According to its principles, the economic aspect of the development should perceive society and the natural environment not as its inhibitors but rather as stimulants [27-30]. The expansion of the area of hop fields planted with new hop varieties (suitable for the production of special beers) will lead to their development. The appropriate composition of the farmland in the area as well as the climatic conditions that suit hops (for more than 1200 years) best predetermine these regions for growing hops and thus contribute to the sustainability of the region's development. In terms of sustainable development, hop growing is also more environmentally friendly for many animal species living in the area. Where there are large fields of rape or similar "technical" crops, there is a loss of game due to the use of heavier agricultural machinery or the consumption of crops unsuitable for game. At the same time, many years of knowledge passed down from generation to generation about the cultivation of hops by qualified local workers help to maintain employment in the area, the settlement of the landscape and its further prosperity.

Profitable farming of agricultural land cultivated in this way will not lead to its sale for construction purposes. Prus [27] further adds that sustainable development in agriculture means such programming of farming production so that it makes reasonable use of natural resources and the environment. It provides sufficient amounts of food while maintaining its high quality. An example is the study by Slavík and Zavadil [31], who deal in their study with the need for supplemental irrigation in Czechia. The hop cannot be cultivated in the Zatec region profitably without modern economical irrigation [32].

\section{Materials and Methods}

\subsection{Research Hypothesis and Data Sources}

In order to evaluate the goal of this research, the following hypothesis was established: The growing popularity of special beers produced by microbreweries in the years 2010-2019 significantly contributed to the development of hop field areas in Czechia; among other plantings of varieties suitable for the production of these beers.

From a methodological point of view, the following procedure was determined to successfully verify the validity of the established hypothesis:

- The indicator of the extent of the hop field area in Czechia in the years 2004-2020 was chosen as the subject of the research. For our purpose, it is a significant indicator of the economic performance of hop growing in Czechia. Indicators of the size of hop production and hop yield per hectare are significantly affected by year-on-year weather changes. The Hop Growers Union of Czechia has become a source of data for the analysis of the development of the hop field area indicator in Czechia (for more details see Section 3.2).

- The development of the number of microbreweries in Czechia in the years 2010-2019, when there was a boom in the microbrewery sector due to significant changes in the consumer behavior of beer drinkers, was chosen as the main indicator for comparison. The Czech-Moravian Association of Microbreweries became a source of data for the analysis of the development of the number of microbreweries in Czechia (for more details see Section 3.2).

- This boom has manifested itself in research in the hop growing sector through the breeding of new hop varieties suitable for the production of special beers, which are the main commodity offered by microbreweries. The data source was statistics from the Central Agricultural Inspection and Testing Institute [3].

- Due to the fact that this is a transnational phenomenon, this article also monitors the development of the microbrewing sector in the USA. The data source was statistics from the Brewers Association [33]. The reason is the interest in buying hop varieties suitable for the production of special beers from Czechia. 
- The development of the extent of the hop field area in Czechia is then statistically evaluated in the form of testing with the development of the indicator of growth in the number of microbreweries in Czechia in a given time horizon (for more details see Section 4.7).

- The results of this research were subsequently confronted in this article with similar research conducted by the Ipsos agency for the Czech-Moravian Association of Microbreweries [34] and match was searched for in the results.

The conclusions of the results of the above research will provide verification of the validity of the hypothesis about the possible connection of the development of the extent of hop field area in Czechia with the development of the production performance of microbreweries in the field of special beers.

\subsection{Methodology of Time Series Evaluation}

The methodology of scientific research contained in our study was based on a description of the development of the monitored quantities, as well as the subsequent comparative analysis of time series of selected indicators and their evaluation. This procedure was used to evaluate the development of, and for the further prediction of, time series for the area of hop fields indicator, (Section 4.1) and also to evaluate the development of another prediction of the number of microbreweries (Section 4.4). The results of this statistical analysis are shown in Figures 2 and 3. For the most concise implementation of the set goal, mainly advanced statistical methods were used, such as Holt's exponential smoothing of time series.

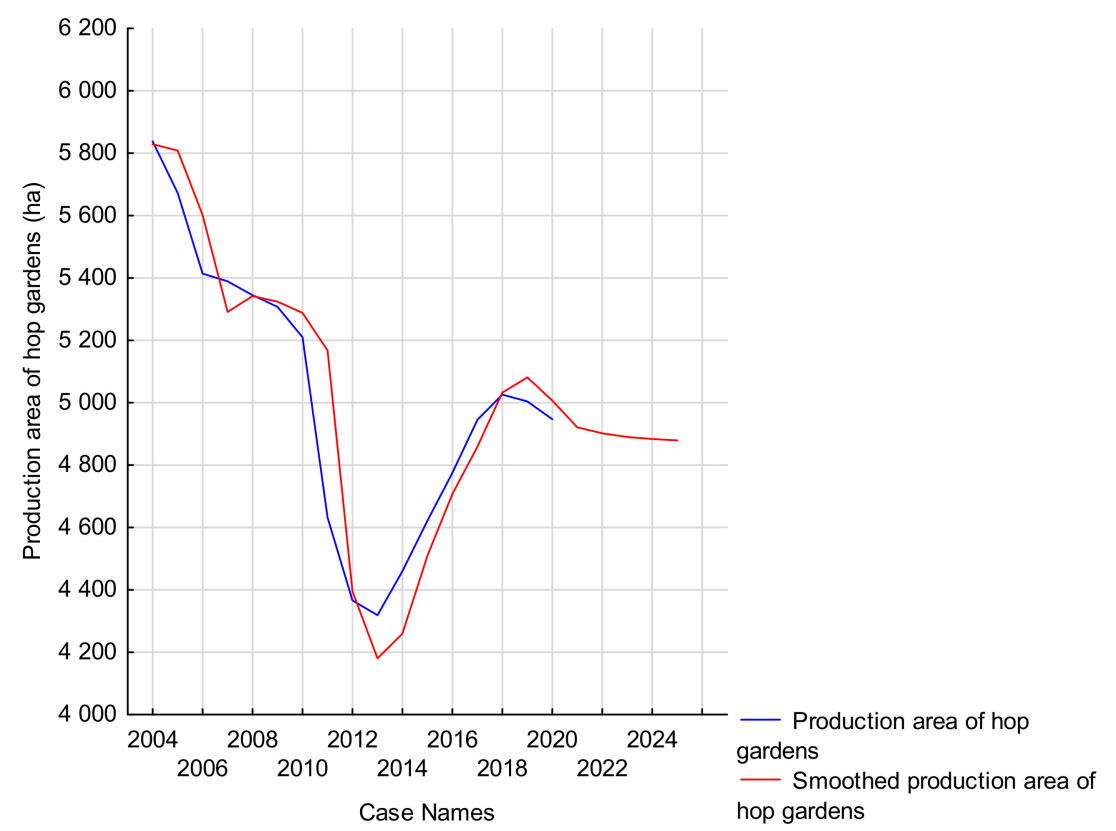

Figure 2. Area development and prediction of production hop fields in the years 2004-2024 in Czechia (in ha) [2].

For time series modeling, it was assumed that each previous value of the time series has an immediate effect on the next value and that the value immediately preceding has greater significance than the older value. Therefore, the method of exponential smoothing, of the second degree (Holt's method), extended by a damped trend was used for the predictions. It is an extension of the original method by a coefficient that dampens the linear trend towards a value to which the series tends to converge in time. The model is thus extended by the phi constant, which has the task of damping the linear trend. A model with M.A.P.E. (mean absolute percentage error) values below $5 \%$, or below $10 \%$ was chosen as a suitable time series model for series prediction and description. The 
coefficients of the model were estimated based on the minimization of the above-mentioned M.A.P.E. indicator.

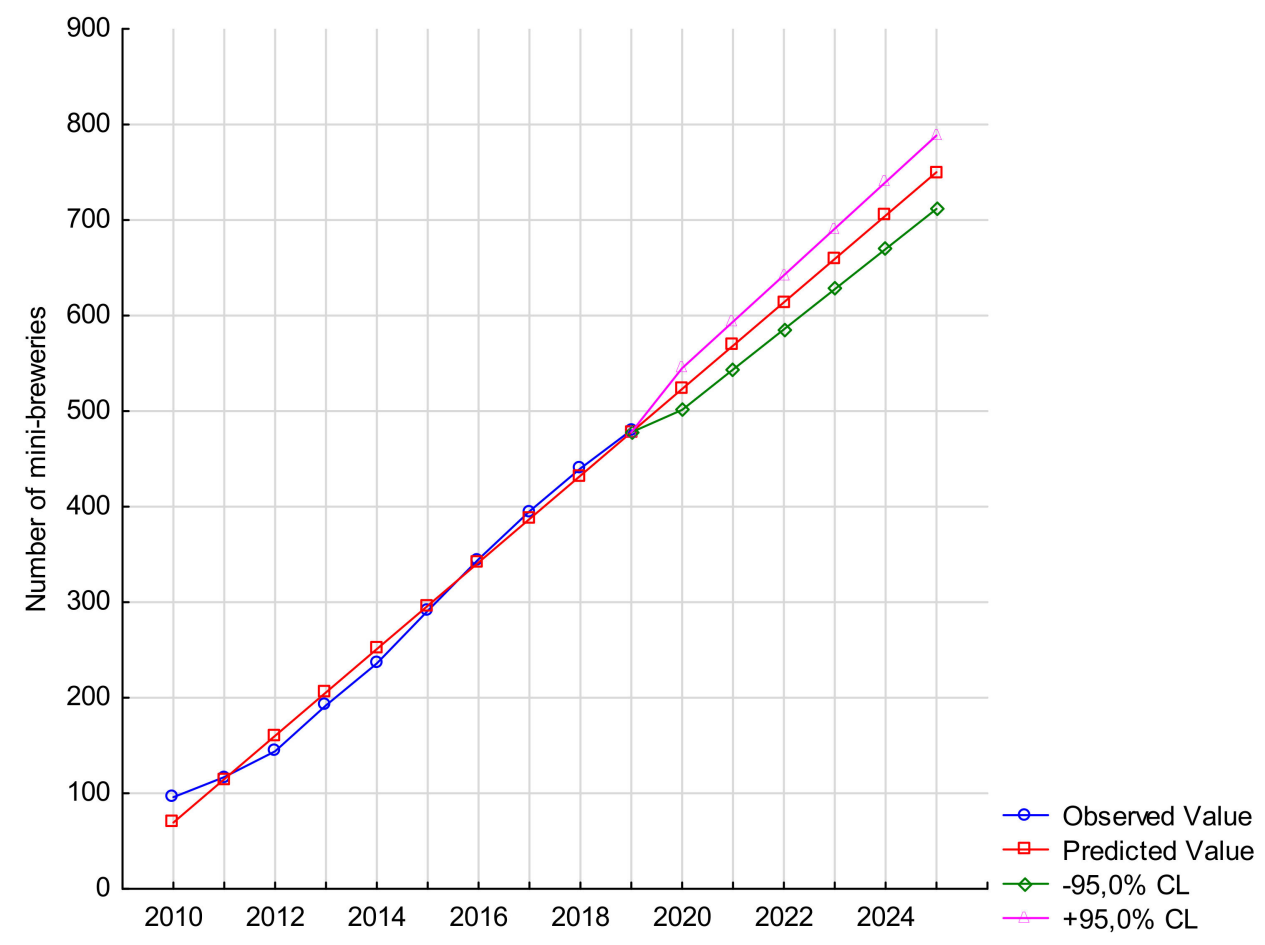

Figure 3. Development of the number of microbreweries in Czechia in the years 2010-2019 and prediction until 2024 [35].

Furthermore, the relationship between the time series of the selected indicators was investigated. For this, the method of correlation of time series was used, when a pair correlation coefficient was calculated for the investigated time series, which allows the investigation of the causal relationship between the variables. The article works with the residues of each time series:

$$
e_{x}=x_{t}-x_{t}^{\prime} \text { and } e_{y}=y_{t}-y_{t}^{\prime}
$$

where $x_{t}^{\prime}=f(t), y_{t}^{\prime}=f(t), t=1,2, \ldots, n$

This makes it possible to verify whether the deviations $e_{x}$ and $e_{y}$ are arranged randomly in time and whether there is a relationship between them. The intensity of the dependence of the time series of the two indicators was determined using the correlation coefficient of the residual deviations. As Hindls et al. [36] stated, the correlation coefficient is determined by the relationship:

$$
r_{e_{x}, e_{y}}=\frac{\sum_{t=1}^{n} e_{x} \cdot e_{y}}{\sqrt{\sum_{t=1}^{n} e_{x}^{2} \cdot \sum_{t=1}^{n} e_{y}^{2}}}
$$

\section{Results}

\subsection{Area of Hop Fields in Czechia and Its Sustainable Development}

Hop is grown in only a few places in Czechia, due to its susceptibility to soil quality (see Figure 1). The total area of hop fields in 2019 in Czechia was about 5003 hectares with a total final production of 7145 tons.

Since the time of the first Czechoslovak Republic, the country has been among the hop producing superpowers. With an almost one-tenth share of the harvest, the Czech 
Republic is the third largest producer of aroma hops in the world after Germany and the US, which together account for over two-thirds of the hop market. In the early 1990s, hops were grown on over 10,000 hectares in the Czech Republic. With the advent of a market economy came a decline, which stopped only in 2013 at 4319 hectares [37].

Most of the original hop fields are gone irretrievably. On the majority of former hopfields, support structures were removed without which hops cannot be grown, and other crops are being grown there. Many original hop fields were only rented by the grower, and if the land owner does not agree with the restoration of hop-growing, the potential hop grower will not succeed. At the same time, the renewal of the hop field is expensive and, as part of the restitution, the new owners did not have the funds for this renewal. As part of the privatization, some owners were not interested in growing hops in the 1990s. In 2010, it was due to the economic situation, as due to the surplus from 2010, when the crop could not be sold, some growers stopped growing hops. Czech hops, especially Žatecký poloraný červeňák, is considered one of the best in the world and also the most expensive. Thus, for economic reasons, some beer producers switched to cheaper hop varieties.

Nevertheless, it seems that the sector (hop growing) has already reached its bottom, and for the five year now the area of hop fields in Czechia has grown slightly. In 2014, the area of hop fields grew for the first time since 2000 (Figure 2). It reached 4460 hectares, which is 3\% more year-over-year. Hop field area has been decreasing for almost 20 years.

The area of production hop fields in Czechia shows considerable fluctuations in the long-term time series in the years 2004-2020. With the accession of Czechia to the EU, there was a sharp decrease in the area from 5838 ha in 2004 to 4319 ha in 2013 (a decrease of $26 \%$ ). Farms have switched to growing less laborious and less risky commodities than hop production. Lower quality but cheaper hop from Germany, the United States and China gradually entered the Czech market. Traditional Czech hop with a high content of $\alpha$-bitter substances is then used by beer producers only for post-hopping of beer. The area of production hop fields, which requires specific soil and climatic conditions, has started to increase since 2014 and is currently around 5000 ha. The predictive Holt model of exponential smoothing with the parameters $\alpha=0.9, \gamma=0.9, \varphi=0.6$ and the error M.A.P.E. $=2.2423 \%$ indicates a slight decrease in the area of hop fields by 2024 (Figure 2).

Since 2014, thanks to support from the Ministry of Agriculture, hop growers have embarked on the extensive restoration of hop-fields. In 2014 alone, 406 new hop fields were established, which is the double the number from the previous years. Market interest in fine aroma hops remains, hence growers are not losing their optimism and are still planting new hop fields.

Towards the end of April 2016, the area of hop fields in Czechia reached 4783 hectares, which is the most in the last 6 years. Year-over-year, this represents an increase of 3.5\%. The increase was caused by the increasing demand for quality Czech hops and the weak European harvest in 2015 [6]. Thus, the storehouses emptied and breweries' stores all over the world, to which $80 \%$ of the local hop production is supplied, ran out. Since then, demand and prices have increased to a level that has begun to cover the costs of hop production. This has also meant that investment in hop production has increased.

It also shows the further expansion of the hop-growing area in Czechia in 2017 to 4945 ha, i.e., a year-on-year increase of 3.39\% [2]. The target of hop growers was to overcome the 5000-hectare limit in the following years, and they were actually successful by 2018 .

However, Czech hop production faces two fundamental problems. The first of them is the age of the domestic hop fields, and the second is their obsolete supporting structures. The average age of these structures is increasing and is even less favorable than the age of hop plants, as $65 \%$ of the structures are over 20 years old. This might change, as in the new EU programming period, hop-growers are given special support and hops are included among the sensitive commodities. Furthermore, the increase in the number of new hop fields is positive, as well as the rate of renovation of the old ones [6].

However, investing in a new hop field is not cheap. According to rough calculations, establishing a hop field of 50 hectares, including related technologies, costs approximately 
CZK 100 million (EUR 3.7 million). One third of the cost goes to the construction of hop growing structures. Harvesting machines, a drying hall and a storage hall cost another third and the rest is for equipment such as sprayers, bine removers, cultivation machines and others [38].

\subsection{Increase in Demand for Czech Hop from US Microbreweries}

Czech hop growers have new opportunities to sell their production. It is the export of hops from new hop fields planted with varieties suitable for the production of special beers.

Not only in Czechia but also in North America, there has been growth in popularity in the production of beer from microbreweries in recent years. The result is a significantly increased interest in Czech hop, which Czech growers cannot satisfy in recent years due to crop failure. New deals from the next harvests will thus be possible to make only in the case of a future above-average harvest.

Growers were able to see a higher interest in Czech hop at the traditional Craft Breweries Conference in Philadelphia in 2016. There were a number of new people interested in Czech hop from the craft breweries segment both in the USA and Canada, including the largest craft breweries from the TOP 10 to the TOP 20.

As late as the 1970s, the number of craft breweries in the United States was around 100. The sharp increase occurred at the end of the last decade, and in 2015 their number reached 4803 (Table 1). Almost three-fifths are microbreweries with an annual production of up to 18,000 hectoliters, less than two-fifths are brewpubs with even smaller production. Four percent are regional craft breweries with production between 18,000 and seven million hectoliters per year [33].

Table 1. Development in the number of microbreweries in the US [33].

\begin{tabular}{ccccccc}
\hline & $\mathbf{2 0 1 5}$ & $\mathbf{2 0 1 6}$ & $\mathbf{2 0 1 7}$ & $\mathbf{2 0 1 8}$ & $\mathbf{2 0 1 9}$ & $\begin{array}{c}\text { 2018 to 2019\% } \\
\text { Change }\end{array}$ \\
\hline $\begin{array}{c}\text { Regional Craft } \\
\text { Breweries }\end{array}$ & 178 & 186 & 202 & 230 & 240 & $4.3 \%$ \\
\hline Microbreweries & 2684 & 3319 & 3956 & 4558 & 2058 & Not comparable \\
\hline Taprooms & 1941 & 2208 & 2503 & 2806 & 3011 & $7.3 \%$ \\
\hline Brewpubs & 4803 & 5713 & 6661 & 7594 & 8275 & $9.1 \%$ \\
\hline $\begin{array}{c}\text { Total U.S. Craft } \\
\text { Breweries }\end{array}$ & & - & - & - & 2966 & Not comparable \\
\hline
\end{tabular}

The sharp increase in the number of small and medium-sized breweries in the USA is evidenced by the fact that at the end of 2018 there were 7698 breweries in the entire USA, of which only 104 were not craft ones or did not belong to the microbrewery or pub brewery category, but to large multinational conglomerates. The number of craft and industrial breweries is clear to the former, but the total volume of the market they occupy was only about $13.2 \%$ in 2018 [39].

\subsection{Increase in the Number of Hop Varieties Suitable for Czech Microbreweries}

Hop breeders are responding to trends in hop growing and brewing, including the advent of microbreweries and special beers, which they mostly focus on. Czechia, as a major world producer of hop, is thus facing the emergence of new varieties. The number of hop varieties, which are now grown on 12 hop fields, could almost double. On most of the planted areas of hop, the traditional and globally sought-after Žatecký poloraný červeňák is grown. In the following years, however, up to 11 more will be added to the list of varieties.

They are not substitutes for the current high-quality hop varieties, but they mean an expansion of the diversity of brewing-valuable substances. Hop breeding, which is one of the decisive tasks of the Žatec Hop Institute, has recently focused on four main 
directions: aromatic hop varieties, bitter varieties, varieties for low structures and varieties with specific aromas used for special beers such as ale, IPA or wheat beer [37]. Aromatic hop varieties will continue to be used for Czech beers, as consumers know them.

\subsection{Development of the Number of Microbreweries in Czechia}

In the early 1990s, there was only one microbrewery in Czechia, U Fleků brewery in Prague, which was popular especially with tourists. Since 2010, there has been a growing number of small beer producers, increasing by tens per year. It all eventually resulted in the establishment of the Czech-Moravian Association of Microbreweries in April 2011, which became an important institution in the local beer market representing its members in the political and economic field [35].

Above all, the positive response of consumers to the offer of specific and unique types of beer had an impact on the rapid increase in the number of microbreweries. Their number increased five times in 2019 compared to 2010. Microbreweries have become popular entertainment for tourists when exploring natural and cultural monuments. The development of the number of microbreweries in the years 2010-2019 shows a linear trend with a high value of the coefficient of determination $\left(R^{2}=0.991\right)$. Figure 3 is a clear look at the current development of the number of microbreweries and the interval forecast until 2024, assuming ceteris paribus.

According to an estimate by the Czech Association of Breweries and Malt-houses, which brings together large breweries, the production of microbreweries in 2013 amounted to 160,000 hectoliters. In 2013, 48 new microbreweries were established in Czechia, bringing their total number up by a quarter to 192 (see Figure 3). The average production was about 730 hectoliters per small producer. In 2014, the above mentioned association expected an increase in this production by more than half to about 200,000 hectoliters. This was about a percentage of the production of all domestic breweries, which brewed over 19 million hectoliters of beer in 2013.

According to the Czech Association of Microbreweries, most microbreweries (in relation to the area of the region) were located in Prague in 2014, where there were 25 of them, and in the Moravian-Silesian Region, especially in the Ostrava region. There, people could choose from 35 producers. There is purchasing power and tourists in Prague, and in the Ostrava region there is a mining tradition of drinking beer and a certain genius loci, which causes microbreweries to thrive there. On the contrary, the fewest microbreweries are in southern Bohemia, but they are appearing there as well. In southern Bohemia, quality beer has always been brewed in large breweries, so there was no need to build microbreweries. As is well known, South Bohemians are also quite frugal and do not want to pay a higher price for beer if they have enough good beer.

As stated by the chairman of the Czech Association of Breweries and Malt-houses [1], František Sámal, a significant increase in microbreweries in recent years is perceived positively by the association, as they bring consumers a wider range and the opportunity to try new and non-traditional beers; they are rather the spice of the Czech brewing industry. They particularly offer people specials, which large industrial breweries do not pay much attention to. That is why the association of large industrial breweries is not afraid of competition from these smaller and mostly even more expensive breweries [40].

The boom of small breweries continued at an unexpectedly fast pace in 2015; there were 50 more in a year, bringing their number to 291. We were surprised, we did not expect such growth ourselves, said the president of the Czech-Moravian Association of Microbreweries [35], Jan Šurán. The potential for growth is still there, there are still a number of large cities where there are few or no microbreweries. The market can easily feed twice the current number. Microbreweries do not compete with each other very much, in contrast with industrial breweries [41].

The number of microbreweries in Czechia increased by a new 50 to almost 400 in 2017; thus, almost every week a new brewery appeared (see Figure 4). 


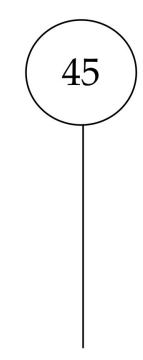

large

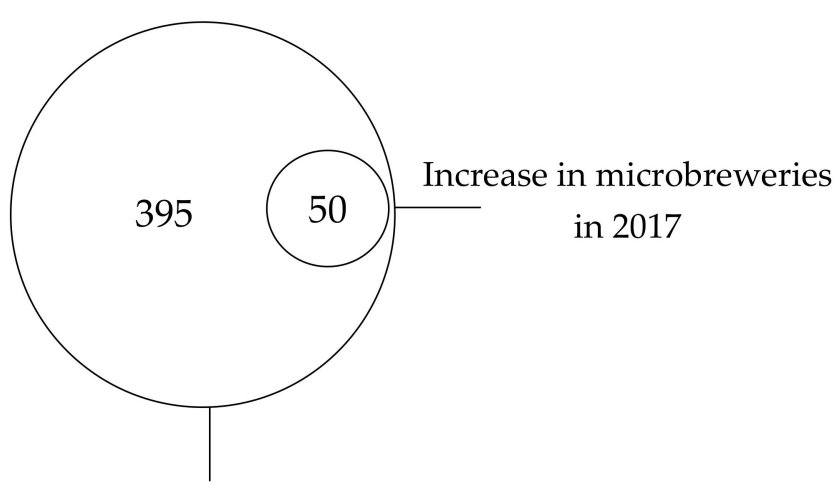

microbreweries

(industrial)

breweries

Figure 4. Numbers of breweries in Czechia in 2017 [35].

The newly established breweries mostly had production of up to 1000 hectoliters of beer per year. However, in 2017, some microbreweries exceeded the production of 10,000 hectoliters, from which they are no longer referred to as microbreweries; the Koníček brewery in Vojkovice is an example [42].

At the end of 2019, there were approximately 480 microbreweries in Czechia, and on average one more was established every week until the 1st quarter of 2020. The total share of microbreweries on the Czech beer market is still quite negligible and is around $2.5 \%$; however, it has a steady upward trend [35].

This tendency is very similar to the development in Great Britain or the USA only with a certain time lag, and domestic breweries still definitely have a place to grow. This is also confirmed by the president of the Czech-Moravian Association of Microbreweries [35], Jan Šuráň. In his opinion, there is room for up to a thousand establishments on the Czech beer market. In addition, the magic number 1000 is also the number of breweries that the Czech lands already had in the Austro-Hungarian Empire [5].

The reasons leading to the ever-increasing number of microbreweries in Czechia are various, i.e., market concentration, the percentage of the total population made up of the 25-39 years age group, and the rising share of domestic beer consumption in cans [43]. However, the role of microbreweries in contrasting with unified "euro beers" from the largest industrial producers cannot be overlooked. They create a colorful environment with new beer styles and various festivals with a brewing theme.

The trend in microbreweries is the production of top-fermented ale-type beers, especially India Pale Ale and American Pale Ale. About 60 producers allow beers to mature in barrels after another alcohol, such as cognac [35].

Unfortunately, the coronavirus-related limitations in 2020 and 2021 are likely to interfere with the optimistic forecast. Microbreweries mainly produce cask beer, for which they do not have sales at the time of restaurant closure. On the other hand, while working from home, some people are looking for a distraction at home by experimenting with brewing beer. The current trend is home-brewing. Czech legislation allows brewing $200 \mathrm{~L}$ of beer per year without paying tax.

\subsection{Survey Conducted among Consumers of Beer from Microbreweries in Czechia}

As the number of small breweries in Czechia continues to increase, so does their popularity as the main destination of a trip. This is shown by a survey within the Rural Year campaign and confirmed by the brewers themselves. According to them, it is not uncommon even for tourists from abroad to come to the microbreweries for beer.

A survey conducted in 2017 by the Ipsos agency for the Association of Small and Medium-Sized Enterprises (AMSP) [34] shows that every seventh tourist even actively searches for breweries or restaurants where they have their own brand of beer as a tourist 
destination. Even though two thirds of tourists do not purposefully look for a small brewery, if they come across it, they prefer to taste the beer. Only one percent of domestic beer fans fundamentally reject beer from microbreweries (Figure 5).

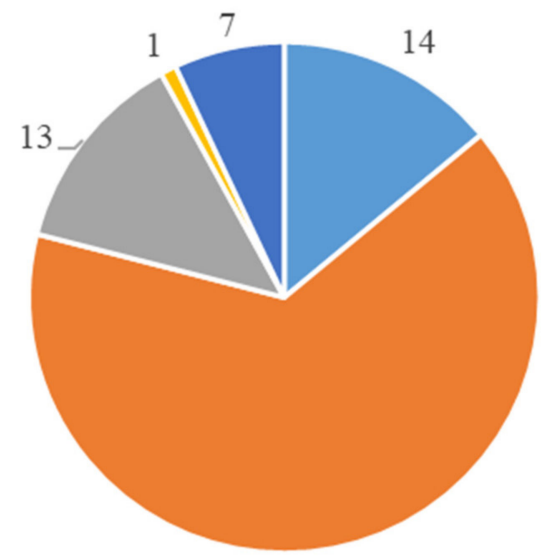

65

- I'm looking for it

- Exceptionally, I prefer large breweries

- I don't know
- I'm not looking for it, but I'd love to try it

- I fundamentally reject it

Figure 5. Relationship of consumers to beer from microbreweries in 2017 (in \% of respondents-adult citizens of Czechia) [34].

It was testing local beers or learning about specific and original tastes that people mentioned in the survey as the main reason to have one beer from a small brewery (Figure 6).

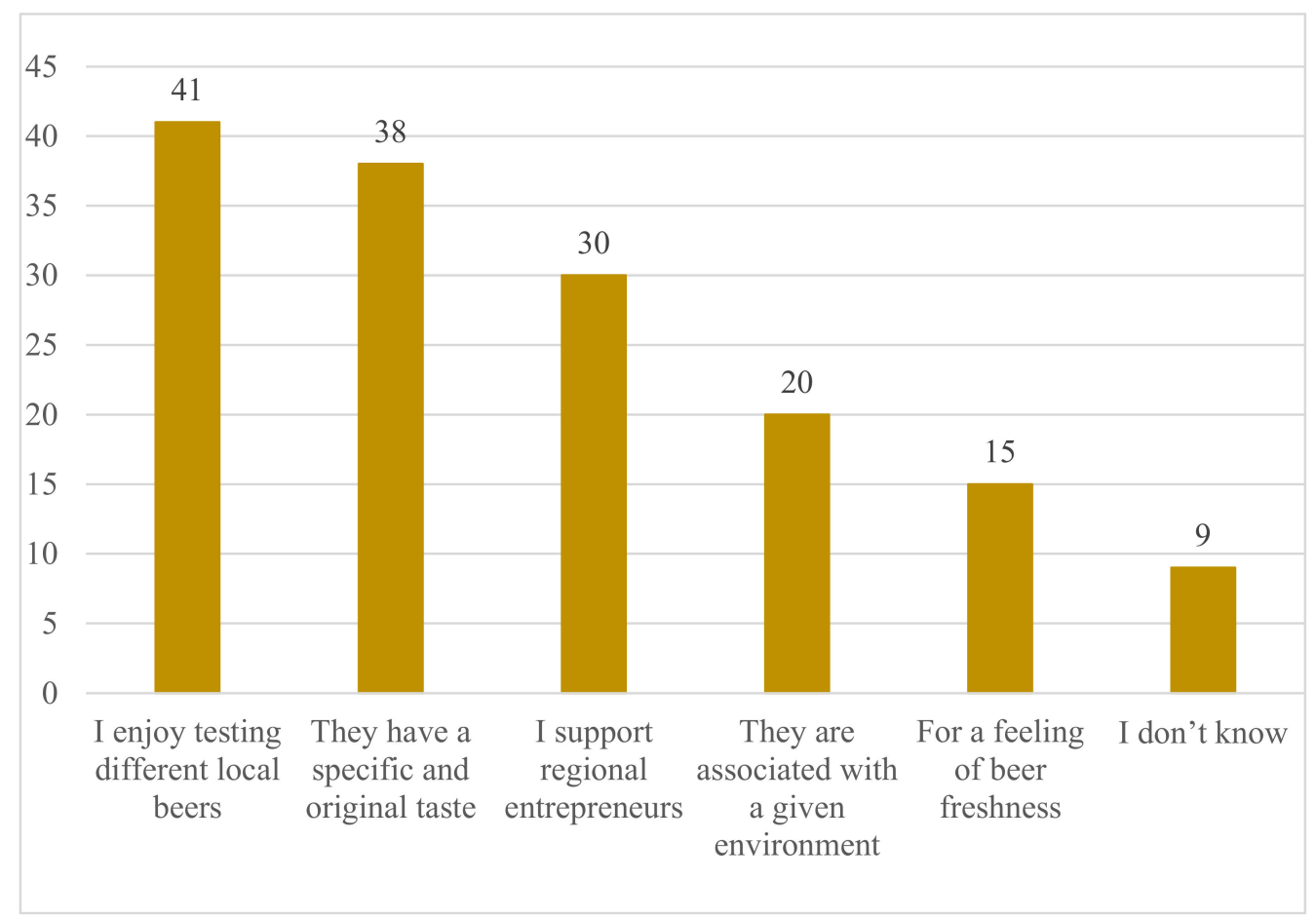

Figure 6. Reasons given by consumers of beer from microbreweries in 2017 (in \% of respondentsadult citizens of Czechia) [34]. 
And $45 \%$ of respondents say they are willing to pay extra for it compared to a pint from a large brewery (Figure 7).

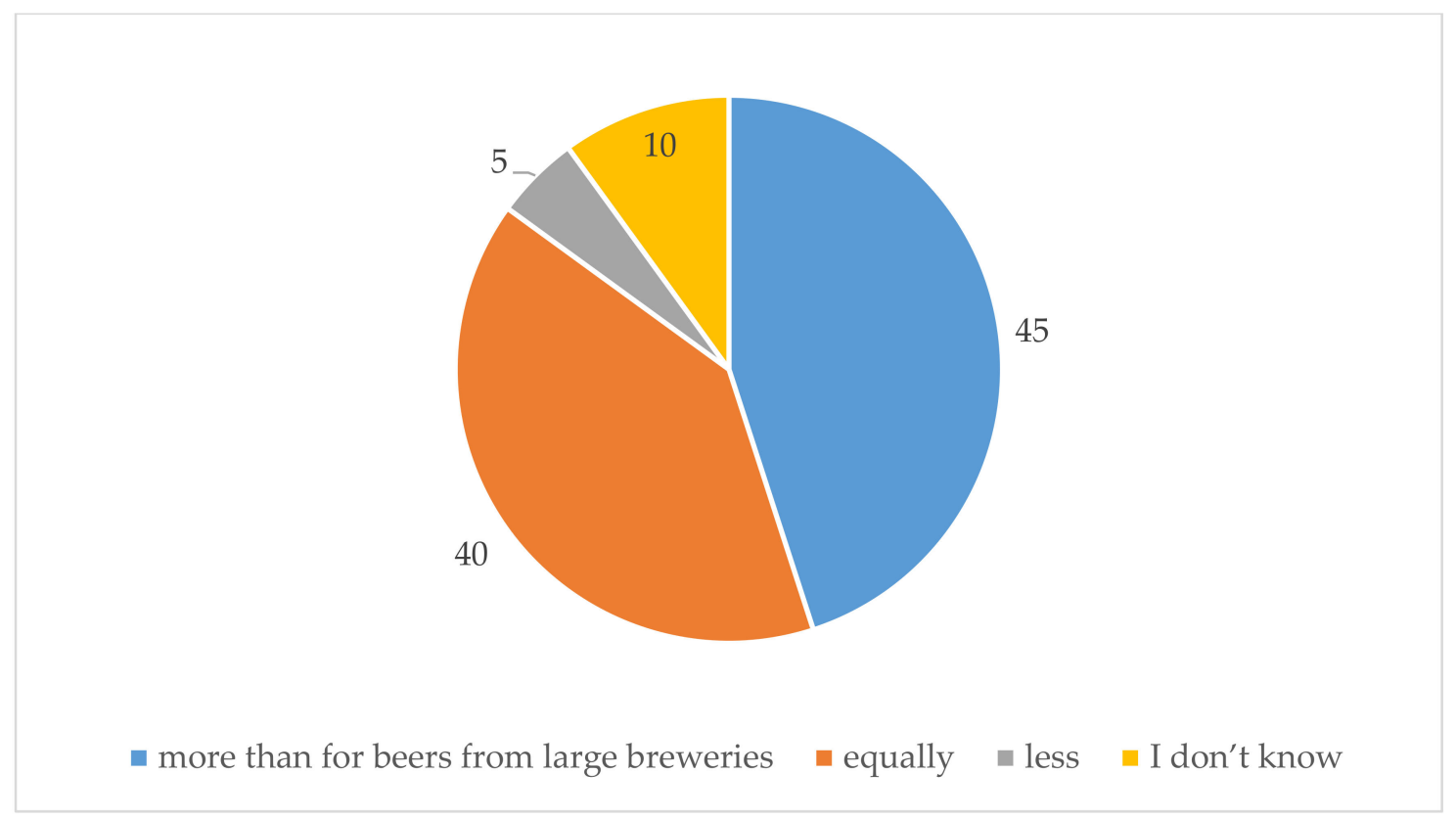

Figure 7. The amount of acceptance of prices for beer from microbreweries in 2017 (in \% of respondents—adult citizens of Czechia) [34].

The research of the Ipsos agency shows the Czech brewing industry that Czechs are now discovering the advantages of a wider range of beers from microbreweries, mainly out of curiosity and they are willing to pay more to know the new product. For microbreweries, this means that they must maintain the higher quality of beer production consumers expect.

\subsection{Survey Conducted among Brewers from Microbreweries}

However, as people from small breweries agree, their customers, despite a wide range, still prefer classic lagers; with small breweries it is usually about unfiltered and unpasteurized beers. As Ivan Hojdar, a partner at the Šumava Brewery Vimperk, states, our recipes mainly reflect the classic tastes of Czech lager, and for eight years of brewing we still stick to this classic concept.

Our favorite beer is light lager Haštal $12^{\circ}$. We are in Czechia, where lagers are popular. So far, other types of beer are looking for a way to customers, says František Marek, CEO of Želiv Monastery Brewery. At the same time, the Premonstratensian Order offers other types of beer-from wheat 12 to a bitter black special-14.

The best-selling beer, as in most breweries, is our 11. If I really should pick up one beer, it would be our 12 and a half Bitter, light lager, which is very popular. In addition, that would be for its fullness and balanced higher bitterness, adds Tomáš Kozák, CEO of Welzl Brewery in Zábřeh.

However, microbreweries are not only an attraction for the consumption of golden liquor. A tour of the brewery, fermentation cellar and other rooms is a matter of course. The number of beer baths is also increasing. Varnsdorf Brewery Kocour attracts visitors with a train, which stops at the brewery's own stop and if visitors arrive by car, they can stay in a sleeping wagon [44].

As the research of brewers showed, customers of microbreweries in the Czech Republic are relatively conservative and prefer lager-type beers, to which they have been accustomed for a long time. However, according to brewers, young people are also more interested in new beer styles and many are also more focused on their consumption. 


\subsection{Verification of the Validity of the Proposed Hypothesis}

Some sources state that the growing area of hop fields in recent years is related to an increase in the number of microbreweries. Microbreweries brew traditional and unique beers from local ingredients. The owners of these breweries strive for a good reputation with the quality of their beer, which returns to them in the form of growing consumer interest. Quality Czech beer cannot be brewed without Czech hop. Predictive models for the development of the area of production hop fields and the development of the number of microbreweries in the years 2010-2019 were used to determine the intensity of dependence between the two indicators. The correlation was dealt with on the basis of residual deviations (Table 2). However, the relationship between the two variables is weak $(\alpha=0.05)$.

Table 2. Correlation matrix of residual components of variables.

\begin{tabular}{ccc}
\hline Variable & Area of Hop Fields & Number of Microbreweries \\
\hline Area of hop fields & 1.00 & +0.31 \\
Number of microbreweries & +0.31 & 1.00 \\
\hline
\end{tabular}

This research partially confirmed the validity of the hypothesis about the positive effect of the growth in the number of microbreweries and the production of special beers on the extent of the hop field area in Czechia. This may be due to the short period of expansion of microbreweries, the fact that special beers account for only a $2 \%$ share of the total beer production in the Czech Republic or the fact that the indicator of the number of microbreweries is monitored, not the total craft beer production in the Czech Republic. Special beers are also produced by large industrial breweries.

Similarly, a study by Elizabeth A. Dobis et al. [45] states that number of breweries is associated with greater hop production (farms and acres) five years later, while warmer temperatures and higher land prices have negative impact on it.

\section{Discussion}

\subsection{Possible Changes in the Hop Growing Sector in Czechia}

The area of hop fields in Czechia is mainly affected by the following factors in connection with the growth in the number of microbreweries.

- New varieties of hops expanding diversity

Bitter hop varieties and those with a specific aroma will expand diversity both for large breweries and especially for small breweries, which are still producing more and more new brands. In addition to more mass production in the form of lagers, Stout, porter, ALE or wheat beer are typical products of local microbreweries, and young people in particular appreciate them to a large extent. It is something new, which until recent years appeared in minimal volume, or even not at all. However, the older generation is looking for a way to know these beers more slowly, as so far, they have been used to mostly consuming beers produced from the Saaz hop variety.

- Beer tourism

Not only castles, chateaux or natural formations are the main destinations of Czech and foreign tourists. Currently, family or restaurant microbreweries are sought after, as well as a number of beer festivals held throughout Czechia. A study published by the Association of Small and Medium-Sized Enterprises and Crafts (AMSP) [46] found that 3 out of 10 Czech tourists visit a small brewery as a destination and almost two-thirds do not resist beer tasting if they come across a brewery on their way. It is therefore clear that regional beers are becoming an interesting tourist attraction for an increasing number of people, and in most cases, they do not mind the higher price of this beer.

Microbreweries are a hit not only in big cities, but especially in small towns and villages. They are an important economic and cultural center of the countryside. They 
support tourism, give people jobs and thus prevent the depopulation of the countryside. Recently, they have begun to connect to beer trails and bring life to regions that would otherwise find it difficult to find another attraction, said Jan Šurán from the Czech-Moravian Association of Microbreweries [35].

A clearly visible combination of the popularity of travel and beer is the number of beer trails throughout the country. Both walking and bike trails. For example, the 22-km-long Krkonoše Beer Trail leads through four microbreweries, one of which, Luční Bouda, is the highest-built brewery in Central Europe.

Similarly, the weekend arrival of young men from Britain, who are used to topfermented beers (which are much cheaper in the Czech Republic thanks to the advantageous exchange rate of the pound), had a positive effect on the sale of special beers and beer exhibitions of microbreweries. Consumption of these beers by foreigners has a significant effect on the sales of the special hop variety market, as most Czech consumers currently prefer bottom-fermented beers, such as Czech light lager-Pilsner produced from the Saaz variety.

- New sales opportunities for hop growers (in the USA)

Czech hop growers have new opportunities to sell their production. It is the export of hops from new hop fields planted with varieties suitable for the production of special beers.

However, the current capacities of Czech hop growing (especially the Saaz variety) are practically sold out for the next few years. According to the Bohemia Hop company, if hop is produced, the level of contractual quantities will certainly rise. It is estimated that the absorption capacity of the American market would make it possible to increase the export of Czech hop by $100 \%$ in two or three years—and possibly even more [47]. In the USA, craft breweries much prefer top-fermented ale and IPA beers. Many foreign hop growers, including the largest competition in Germany, have therefore begun to focus on hop suitable for these types of beer and have reduced the production of hop suitable for bottom-fermented lager beer, such as Žatecký poloraný červeňák. This contributed to the fact that the Chmelarstvi, druzstvo Zatec perceives a greater demand for Czech hop in the world precisely for the needs of lager beers [37]. At the same time, it enables the expansion of hop field areas for the cultivation of hop varieties suitable for the production of special beers in microbreweries and their export to the USA.

The size of the hop market in the USA is best evidenced by its first place in the world as a producer and the fact that hop production in the USA reached 39,526 tons (2016), while in Czechia, which was in third place, it was only 7712 tons (the International Hop Growers' Convention (IHGC)) [48]. This gives Czech hop growers the assurance that they can sell hops abroad as the area of hop fields increases.

- Possibilities for the creation of new microbreweries

The topic of discussion is also the question of how many small beer producers are able to prosper on the Czech beer market. Microbreweries were constantly being established in the monitored period, and although it is possible that the annual increments will decrease over time, around 100 to 200 of them could still be established. In contrast to the demise of microbreweries, between 2009 and 2019 these were only units per year, and in the vast majority of cases these were in advance inappropriately evaluated and poorly implemented projects [35]. However, these facts relate to the period before the coronavirus pandemic, which also significantly affected the sector due to government restrictions leading to the partial closure of microbreweries.

\subsection{Resulting Recommendations for Consumers}

Despite the limited substitution of special beers and the conditions of their sale, there is the possibility for customers to switch to another (or newly established) microbreweries, which can be used by consumers. The variety of beers from microbreweries thus gives consumers a choice in the event of their dissatisfaction with the quality of the beer at a particular brewery. 


\subsection{Resulting Recommendations for the State}

The state should continue to support the development of the hop growing industry in the Czech Republic in the form of subsidy programs both from the budget of the Ministry of Agriculture of the Czech Republic and from EU sources. These are mainly subsidy programs for the renewal of old hop fields or the construction of new ones.

\subsection{Limitations of the Research}

This research article was based mainly on knowledge about the development of the number of microbreweries and the offer of special beers in Czechia and the USA. It would undoubtedly be interesting to supplement the knowledge about such important producers of special beers as Germany or the United Kingdom.

\section{Conclusions}

The beer market in Czechia has long been dominated by several large industrial breweries producing more than 21.3 million hectoliters of beer per year (2018). For these large beer producers, one cannot speak of any craft production, but of technological and industrial production. The boom in microbrewing can be considered a global phenomenon, but different circumstances in each country have led to it. In Czechia, these were mainly errors on the supply side at the time, moreover, influenced by the demand for quality beer. The Czech relationship with beer is very unique (national drink) and current domestic consumers increasingly demand higher quality for the product, which they also drink on average over $140 \mathrm{~L}$ per year.

For microbreweries, the support of pub attendance is key, so it is necessary to invest in new types of beer and other activities that should attract people to restaurants and pubs. The number of small breweries in Czechia-those where less than 10,000 hectoliters of beer are brewed annually—reached 480 at the end of 2019. In 2019 alone, 40 new operations were established. Even though a few years ago, when beer was brewed in half the places, people in the industry claimed that the market was saturated, today many of them are inclined to believe that microbreweries can still grow a lot. Even though they cannot compete with the big ones in terms of production volume (they account for about $2 \%$ of the total production of breweries in Czechia), it is microbreweries that teach Czechs to discover new types or tastes of beer. In addition, large breweries are adapting, as they now produce special beers more often than before.

However, the area of hop fields in Czechia has long been influenced mainly by the sale of hop varieties intended for classic bottom-fermented beers. The reason for this is both their consumption in Czechia and their export abroad. The production of some varieties of Czech hops have been already sold out for the next 10 years.

In order to ensure the increasing production of specialty beers by microbreweries in Czechia, the expansion of hop fields planted with suitable hop varieties is necessary. This makes the meaningful use of farmland for production of agricultural commodities possible.

Due to the limited extent of the usable area of farmland for planting new hop fields (given the specific quality of the soil) required for efficient hop cultivation, there should be no restriction on growing important agricultural commodities essential for the sustainable state of self-sufficiency of the Czech Republic in food production.

Based on the analysis of available data, studies of professional publications, as well as findings from our own research and statistical analyses, it can be stated that the established hypothesis on future development of the hop field area in Czechia due to the offer of special beers produced by microbreweries has been confirmed. The expansion of the area of hop fields planted with new hop varieties suitable for the production of special beers also contributed to this.

However, this offer depends mainly on the consumer habits of the population and especially on the possibility of consuming special beers in the premises of microbreweries or restaurants. This is currently not entirely possible due to state restrictions related to the coronavirus pandemic. Therefore, it will depend on both the current level of state support 
for this sector and the length of this transitional period. The habits of beer consumers should not change significantly in this relatively short period, and based on the results of statistical tests, it is possible to assume both an increase in the area of hop fields and the production of special beers in microbreweries in Czechia in the future.

Author Contributions: Conceptualization, L.S.; methodology, M.P. and M.Š.; software, R.S.; validation, K.Š. and M.Š.; formal analysis, K.Š.; investigation, L.S. and L.K.; resources, M.P. and M.Š.; data curation, L.S.; writing — original draft preparation, K.Š. and R.S.; writing—review and editing, M.P., L.K. and D.H.; visualization D.H.; supervision, L.S.; project administration, K.Š.; funding acquisition, L.S. All authors have read and agreed to the published version of the manuscript.

Funding: This research was funded by the Faculty of Economics and Management, Czech University of Life Sciences in Prague, grant number 2020B0002.

Institutional Review Board Statement: Not applicable.

Informed Consent Statement: Not applicable.

Conflicts of Interest: The authors declare no conflict of interest.

\section{References}

1. Czech Association of Breweries and Malt-Houses. Available online: http://ceske-pivo.cz/fakta-a-zajimavosti (accessed on 16 January 2021).

2. Czech Statistical Office (CZSO). Available online: https://www.czso.cz/csu/czso/320198-14-r_2014-1300 (accessed on 6 January 2021).

3. Central Agricultural Inspection and Testing Institute. Available online: http://eagri.cz/public/web/ukzuz/portal/chmelu-sedarilo-letosni-sklizen-je.html (accessed on 6 January 2021).

4. Ministry of Agriculture of the Czech Republic. Available online: http://eagri.cz/public/web/ukzuz/portal/trvale-kultury/ plochy-chmelnic-04-2020.html (accessed on 4 July 2021).

5. Magazín EGO! Experiment roku 2020. Uvař si vlastní pivo. Hospodářské Nov. 2020, 3, 17-21.

6. Hop Growers Union of Czechia. Available online: http://www.czhops.cz/index.php?option=com_content\&view=section\& layout=blog\&id=1\&Itemid=28\&lang=cs (accessed on 18 December 2020).

7. Rybáček, V. Hops Production and Science on a New Path. Rostl. Výroba 1991, 37, 625-626.

8. Sbardella, M.; Racanicci, A.M.C.; Gois, F.D.; de Lima, C.B.; Migotto, D.L.; Costa, L.B.; Miyada, V.S. Effects of dietary hop (Humulus lupulus L.) $\beta$-acids on quality attributes, composition and oxidative stability of pork meat. J. Sci. Food Agric. 2018, 98, $2385-2392$. [CrossRef] [PubMed]

9. Oladokun, O.; Tarrega, A.; James, S.; Smart, K.; Hort, J.; Cook, D. The impact of hop bitter acid and polyphenol profiles on the perceived bitterness of beer. Food Chem. 2016, 205, 212-220. [CrossRef]

10. Hough, J.S.; Briggs, D.E.; Stevens, R.; Young, T.W. Beer 17ah ra and Beer Quality Malting and Brewing Science: Volume II Hopped Wort and Beer; Springer: Boston, MA, USA, 1982.

11. De Keukeleire, D. Fundamentals of beer and hop chemistry. Quim. Nova 2000, 23, 108-112. [CrossRef]

12. Schönberger, C.; Kostelecky, T. 125th Anniversary Review: The role of hops in brewing. J. Inst. Brew. 2011, 117, 259-267. [CrossRef]

13. Hieronymus, S. For the Love of Hops: The Practical Guide to Aroma, Bitterness and the Culture of Hops; Brewers Publications: Boulder, CO, USA, 2012.

14. Oladokun, O.; Tarrega, A.; James, S.; Cowley, T.; Dehrmann, F.; Smart, K.; Cook, D.; Hort, J. Modification of perceived beer bitterness intensity, character and temporal profile by hop aroma extract. Food Res. Int. 2016, 86, 104-111. [CrossRef]

15. Keast, R.S.; Breslin, P.A. An overview of binary taste-taste interactions. Food Qual. Prefer. 2003, 14, 111-124. [CrossRef]

16. Henning, J.A.; Gent, D.H.; Townsend, M.S.; Woods, J.L.; Hill, S.T.; Hendrix, D. QTL analysis of resistance to powdery mildew in hop (Humulus lupulus L.). Euphytica 2017, 213, 411-420. [CrossRef]

17. Nesvadba, V.; Krofta, K. New hop variety Agnus as the result of breeding process innovation in Czechia. Rostl. Výroba 2002, 48 , 513-517.

18. Patzak, J. Characterization of Czech hop (Humulus lupulus L.) genotypes by molecular methods. Rostl. Výroba 2002, 48, 343-350. [CrossRef]

19. Chen, L.L.; Chen, H.S.; Zou, C.; Liu, Y. The Impact of Farmland Transfer on Rural Households' Income Structure in the Context of Household Differentiation: A Case Study of Heilongjiang Province, China. Land 2021, 10, 362. [CrossRef]

20. Ranjan, P.; Wardropper, C.B.; Eanes, F.R.; Reddy, S.M.; Harden, S.C.; Masuda, Y.J.; Prokopy, L.S. Understanding barriers and opportunities for adoption of conservation practices on rented farmland in the US. Land Use Policy 2019, 80, 214-223. [CrossRef]

21. Jin, S.; Jayne, T.S. Land Rental Markets in Kenya: Implications for Efficiency, Equity, Household Income, and Poverty. Land Econ. 2013, 89, 246-271. [CrossRef]

22. Kijima, Y.; Tabetando, R. Efficiency and equity of rural land markets and the impact on income: Evidence in Kenya and Ugandafrom 2003 to 2015. Land Use Policy 2020, 91, 91. [CrossRef] 
23. Azadi, H.; Vanhaute, E.; Janeckova, K.; Sklenicka, P.; Teklemariam, D.; Feng, L.; Witlox, F. Evolution of land distribution in the context of development theories. Land Use Policy 2020, 97, 104730. [CrossRef]

24. Huettel, S.; Wildermann, L.; Croonenbroeck, C. How do institutional market players matter in farmland pricing? Land Use Policy 2016, 59, 154-167. [CrossRef]

25. Ustaoglu, E.; Collier, M.J. Farmland abandonment in Europe: An overview of drivers, consequences, and assessment of the sustainability implications. Environ. Rev. 2018, 26, 396-416. [CrossRef]

26. Xie, H.; Wang, P.; Yao, G. Exploring the Dynamic Mechanisms of Farmland Abandonment Based on a Spatially Explicit Economic Model for Environmental Sustainability: A Case Study in Jiangxi Province, China. Sustainability 2014, 6, 1260-1282. [CrossRef]

27. Prus, P. Sustainable farming production and its impact on the natural environment—Case study based on a selected group of farmers. In Proceedings of the 8th International Scientific Conference on Rural Development-Bioeconomy Challenges, Akademija, Lithuania, 23-24 November 2017; Raupeliene, A., Ed.; Aleksandras Stulginskis University: Akademija, Lithuania, 2017; pp. 1280-1285.

28. Veselá, K. Impact of Czech Republic Accession to European Union on Sugar Imports. Listy Cukrov. A Reparske 2020, 136, 422-425.

29. Kosiciarova, I.; Kadekova, Z.; Dzupina, M.; Kubicova, L.; Dvorak, M. Comparative Analysis of Private Labels-Private Labels from the Point of View of a Millennial Customer in Slovakia, Czech Republic and Hungary. Sustainability 2020, 12, 9822. [CrossRef]

30. Beranova, M.; Navratilova, M. Organic Agriculture in the Context of Sustainable Development of Czechia and Norway. In Mezinarodni Konference Udrzitelny Rozvoj 2019: Vybrane Problemy Environmentalni a Regionalni Politiky. Selected Issues On Environmental And Regional Policy, Ceske Budejovice, Czechia, 14-15 March 2019; Riha, R., Ed.; Vysoka Skola Evropskych A Regionalnich Studii: Ceske Budejovice, Czechia, 2019; pp. 17-23.

31. Slavík, L.; Zavadil, J. The need of supplemental irrigation in the Czech Republic. Rostl. Výroba 2001, 47, 507-512.

32. Slavík, L. Utilization of trickle irrigation and microsprinkling of hop irrigation. Rostl. Výroba 2000, 46, 457-463.

33. Brewers Association. Available online: https://www.brewersassociation.org/statistics/number-of-breweries/ (accessed on 23 January 2021).

34. IPSOS Agency for Association of Small and Medium-Sized Enterprises and Crafts of the Czech Republic. Available online: https:/ / www.ipsos.com/cs-cz (accessed on 5 January 2021).

35. Czech-Moravian Association of Microbreweries. Available online: http:/ / www.minipivo.cz/ (accessed on 23 January 2021).

36. Hindls, R.; Hronová, S.; Novák, I. Metody Statistické Analýzy pro Economy; Management Press: Praha, Czech Republic, 2000.

37. Chmelarstvi, Druzstvo Zatec. Available online: http://www.chmelarstvi.cz/profil-spolecnosti/chmelarstvi-druzstvo-zatec (accessed on 16 January 2021).

38. Kütner, D. Český Chmel Zná Svět už Stovky Let. E15, 16 September 2016.

39. National Beer Sales \& Production Data. Available online: https://www.brewersassociation.org/statistics-and-data/nationalbeer-stats / (accessed on 16 January 2021).

40. Kütner, D. Počet minipivovarů loni stoupl o čtvrtinu. E15, 24 April 2014.

41. Sůra, J.; Černý, A. Každý Týden Nový Pivovar. MF Dnes 2016, 23, 5.

42. ČTK. Minipivovarů Jsou už Čtyři Stovky. E15 2018, 21, 6.

43. Maier, T. Sources of Microbrewery Competitiveness in Czechia. AGRIS Line Pap. Econ. Inform. 2016, 8, 97-110. [CrossRef]

44. Petř́iček, M. Místo na hrad do pivovaru. MF Dnes 2017, 17, 5.

45. Dobis, E.; Reid, N.; Schmidt, C.; Goetz, S.J. The role of craft breweries in expanding (local) hops production. J. Wine Econ. 2019, 14, 374-382. [CrossRef]

46. Association of Small and Medium-Sized Enterprises and Crafts of the Czech Republic. Available online: https://www.spcr.cz/ en/news (accessed on 5 January 2021).

47. Kütner, D. Američany láká český chmel. E15, 30 June 2016.

48. The International Hop Growers' Convention (IHGC). Available online: http:/ /www.hmelj-giz.si/ihgc/ (accessed on 28 April 2021). 